\title{
Role of Silicone on Molded Flexible Polyurethane from Soy Oil
}

\author{
Flora Elvistia Firdaus \\ Dept. of Chemical Engineering, Jayabaya University \\ Jl. Pulomas Selatan Kav 23 Jakarta Timur- 13210, Indonesia \\ Tel: 62-21-858-3591_E-mail: flora_elvistia@yahoo.com
}

Received: December 19, 2011 Accepted: January 6, $2012 \quad$ Published: February 1, 2012

doi:10.5539/ijc.v4n1p45

URL: http://dx.doi.org/10.5539/ijc.v4n1p45

The research is financed by Indonesia Department of Higher Education in the scheme of National Block Grant Competence

\begin{abstract}
Polyurethane foam (PUF) is formed by a chemical reaction of polyol and isocyanate. The aim of this work is to understand the effect of silicone on molded polyurethane. Silicone perform as surfactant, which influencing the interfacial level as well as within bulk. The method used was one step process, which are simultaneously carried out a blending polyol, TDI $(2,4)$ :MDI $\left(4,4^{\prime}\right)(80: 20)$, distilled water into different volumes of molding. The properties of molded polyurethane were determined by its polymer density, compressive strength, and cellular structures.
\end{abstract}

Keywords: Soy oil, Silicone, Polyurethane, Density

\section{Introduction}

Polyurethane foam (PUF) is one the most useful polymeric materials regard to processing methods and mechanical properties. The resulting PUF can be rigid crystalline plastic, flexible elastomer, or viscoelastic gel. This wide range of achievable properties makes PUF an indispensable component in building construction, consumer products, transportation and medical devices (Herrington, 1997). Similar to nearly all polymeric materials PUF relies on petroleum oil as the feedstock for its major components: hydroxyl containing polyols and isocyanates. Using bio-renewable feedstocks for PUF manufacturing becomes highly desirable for both economic and environmental reasons (Schaefer, 2005). Vegetable oils can be potential replacements for polyols. Several methods are currently known to add hydroxyls at the unsaturated sites: hydroformylation followed by hydrogenation (Lsenko et al., 2004), epoxidation followed by oxirane opening (Petrovic et al., 2002), ozonolysis followed by hydrogenation (Petrovic, 2005). Early research work has focused on synthesizing elastomers and rigid foams from entirely natural polyols which were proven to be successful. However, challenges remain in making flexible foams, the most significant polyurethane product, using entirely natural polyols (Petrovic, 2005; Javni et al., 2002; John et al., 2002).

Soybean is a preferred feedstock for new industrial oil product applications due to its relatively unreactiveness in polymer formulations. The fatty composition in percentage by weight, (16:0) $17.75 \%$; (18:0) $3.15 \%$; (18:1) $23.2 \%$; (18:2) $55.5 \%$ and (18:3) $6.31 \%$ (Aneja, 2002). This oil can be hydroxylated to the carbon-carbon double bonds with peroxy acids or alcoholysis with triol like glycerol or triethanolamine to reach a hydroxyl value which is useful for flexible foam production (Casado, 2009). However, the SEM images of entirely soybean polyol provided show large amounts of closed cells (John, 2002). Replacing part of petroleum polyol with soybean oil-derived polyol found improvements in foam load properties without concerning in the number of open cells. (Herrington, 2006; Babb, 2006; Lysenko, 2006).

The soft phase of polyurethane foam is usually a polyfunctional alcohol or polyol phase glycols such as ethylene glycol is commonly used for chain extension to form hard segments. Chain extender plays a very important role in polyurethane. Without a chain extender, polyurethane formed by directly reacting diisocyanate and polyol generally which may exist very poor physical properties and often does not exhibit microcellular separation (Wang, 1998). 
As one of reagent, surfactants were used in the PU synthesis plays a crucial role in influencing at the interfacial level as well as within the bulk. The interfacial processes come into play as early as when the initial bubbles are formed in the liquid Silicone based surfactants (Kanner, 1969). The properties of the PUF depends on the its polyol type such as hydroxyl value, amount of surfactant, and blowing agent (Lim, 2008).

\section{Materials and Methods}

\subsection{Materials}

Soybean oil with Iodine value of $53,89 \mathrm{gram}$ Iod/100 gr sample, viscosity was $65,5278 \mathrm{cps}$, acid value was 0,024 $\mathrm{mgr} \mathrm{KOH/} \mathrm{sample,} \mathrm{were} \mathrm{purchased} \mathrm{from} \mathrm{P.T} \mathrm{Variatama} \mathrm{Jakarta.} \mathrm{Hydrogen} \mathrm{peroxide,} \mathrm{acetic} \mathrm{acid,} \mathrm{sulphuric} \mathrm{acid,}$ butanol, and ethylene glycol were also used. All materials were used as received without further purification.

\subsection{Preparation of flexible PU foam}

The ratios of soy epoxide to alcohol used in this study were $1: 1 ; 1: 3 ; 1: 5$ and $1: 6$ (mol/mol). Hydroxylation of monohydric alcohols (methanol and butanol) to soy epoxide respectively yields polyol 1 (P1) and polyol 2 (P2), and with dihydric alcohol; ethylene glycol, yield polyol 3 (P3). They respectively blend into petroleum polyol yields PUF 1, PUF 2, and PUF 3.

\section{Results and Discussion}

\subsection{Property measurement of soy based polyol}

The optimized conditions found in synthesizing polyol (P1, P2, and P3), were at 2 hour of reaction, with 1:6 (mol/mol) for P1; $1: 5$ (mol/mol) for P2, and 1:5 (mol/mol) for P3 at $110{ }^{\circ} \mathrm{C}$ (Figure 1). It assumed by $1 \mathrm{~h}$ of reaction the soy epoxide has not met the optimized hydroxylation. The polyols existed from hydroxylation of epoxide to butanol is more viscous than methanol, and ethylene glycol which were 569,431 cps (P2); 232,828 cps (P1), and 18,864 cps (P3), this much related to its the molecular weight.

The hydroxyl value of polyol were synthesized from monohydric alcohol; methanol and butanol, were more higher than dihydric alcohol; ethylene glycol. The values were 578,923 $\mathrm{mgr} \mathrm{KOH/gr}$ for (P1), 549,66 mgr $\mathrm{KOH} / \mathrm{gr}$ for (P2), and 308,55 $\mathrm{mgr} \mathrm{KOH} / \mathrm{gr}$ for (P3).

The results above has indicated that the inclusion of short chain $\mathrm{C}_{1}$ (metha-) and $\mathrm{C}_{4}$ (buta-) of monohydric alcohols to the synthesis of polyol has met the optimize condition of reaction. The dihydric alcohol of ethylene glycol which previously expected to contribute more OH's, has voided the theoretical analysis.

\subsection{Characterization and property measurement of PUF}

\subsubsection{Density}

Generally, foams which were synthesized without using silicone, relatively have higher density to those were synthesized with silicone. Foams with volume of molding $250 \mathrm{ml}$ and $500 \mathrm{ml}$ have a comparable density (Table 2). The volume of molding can affected to foam density. Moreover, the foam density has relationships to hydroxyl value (Figure 2).

\subsubsection{Compressive strength}

There compressive strength of three type of foams were not significantly different, eventhough PUF1 seems the lowest amongs others (Table 3).

\subsubsection{Cell morphology}

The cell size of PUF2 and PUF3 reveals slightly more larger compared to PUF1 this could be effected to the exceeds water content on synthesizing P1. SEM micrograph was used to take images of cured solid polyurethane foams PUF1, PUF2, and PUF3 which used petro in the same composition, it shown in (Figure 3). The cell size of PUF2 and PUF3 reveals slightly more larger compared to PUF1 this could be effected to the exceeds water content in synthesized P1.

\section{Conclusion}

It is found the used of silicone and volume molding on polyurethane synthesis can be effected to density, mechanical strength, and morphology of the foams. The type of alcohols (monohyric or polyhydric) on producing poyols effected to time of completion. Overall it effected to the properties of polyurethanes.

\section{Acknowledgements}

This work was fully supported by Indonesia Department of higher education. 


\section{References}

Aneja A. (2002). Structure property relationships of flexible polyurethane foams, Dissertation. Virgnia Polytechnic institute and state university, p.11.

Babb D., Phillips J., \& Keillor C. (2006). Proceedings of polyurethanes technical conference. Salt Lake city, UT, pp. 189-93.

Javni I., Petrovic Z. S., \& Guo A. (2002). Thennal stability of polyurethane based on vegetable oils. J. Appl. Polym Sci.: part B: $\quad$ Polym http://dx.doi.org/10.1002/1097-4628(200008227)77:8<1723AID-APP9>.3.0.CO:2-K

John J., Bhattacharya M., \& Turner R. B. (2002). Characterization of polyurethane foams from soybean. J. Appl. Polym. Sci., 86, 3097-3107. http://dx.doi.org/10.1002/app.11322

Herrington R., \& Hock K. (1997). Flexible polyurethane foams, 2 nd edition. Midland; Dow Chemical Co.

Herrington R., \& Malsam J. (2006). US Patent Application 2005/0070620.

Kanner B., \& Decker T. G. (1969). Urethane foam formation - role of the silicone surfactant. Journal Cell Plast., 5(1), 32-39. http://dx.doi.org/10.1177/0021955X6900500104

Lim, Kim, \& Kim. (2008). Effect of silicone surfactant in rigid polyurethane foams. Express polymer letters, 2(3), 194-202. http://dx.doi.org/10.3144/expresspolymlett.2008.24

Lsenko Z., Morrison D. L., Babb D. A., Unning D. L., Derstine C. W., Gilchrist J. H., et. al. (2004). WO Patent 2004096744 A2.

Lsenko Z., Babb D. A., Stutts K. J., Robbyn P., Zhang M., \& Schrock A. K. (2006). WO Patent 2006118995 A1.

Petrovic Z. S., Cevalos M. J., Javni I., \& Schaefer D. W. (2005). Justice R, Soy oil based segmented polyurethanes. J. Polym Sci. Part B: Polym Phys, 43(22), 3178-3190.

Petrovic Z. S., Javni I., Guo A., \& Zhang W. (2002). US Patent 6, 433, 121.

Petrovic Z. S., Zhang W., \& Javni I. (2005). Structure and properties of polyurethanes prepared from triglycerides polyols by ozonolysis. Biomacromolecules, 6, 713-719. http://dx.doi.org/10.1021/bm049451s

Schaefer B. F. (2005). When Do Rocks Become Oil? Science, 308(5726), 1267-1268. http://dx.doi.org/10.1126/science.1113158

Thirumal M., Dipak D., Singha N. K., Manjuntah B. S., \& Naik Y. P. (2004). Effect of foam density on the properties of water blown rigid polyurethane. J. Appl. Polym Sci., 108(3), 1810-1817. http://dx.doi.org/10.1002/app.27712

Wang. (1998). Polydimethylsiloxane Modification of Segmented Thermoplastic Polyurethanes and Polyureas.

Dissertation, Virginia Polytechnic institute and state university, p.14.

Table 1. Characteristics of soy polyols as prepolymer for PUF

\begin{tabular}{llll}
\hline \hline Polyol Property $^{\text {a }}$ & P1 & P2 & P3 \\
Hydroxyl value (mgr KOH/gr) & 578.923 & 549.66 & 308.55 \\
Oxirane Number (\%) & 0.11 & 0.09 & 0.079 \\
Viscosity (cps) & 231.828 & 569.431 & 18.864 \\
Functionality & 1 & 1 & 2 \\
Color & Pale Yellow & Pale yellow & Brown \\
\hline \hline
\end{tabular}

a2 hour reaction and temperature $110{ }^{\circ} \mathrm{C}$ 
Table 2. Density of PUF

\begin{tabular}{llllll}
\hline \hline $\begin{array}{l}\text { Series 1, } 1^{\mathrm{a}, \mathrm{b}} \\
\text { Type of } \\
\text { PUF }\end{array}$ & $\begin{array}{l}\text { Density } \\
(\mathrm{gr} / \mathrm{cm} 3)\end{array}$ & $\begin{array}{l}\text { Average } \\
\text { Density }\end{array}$ & $\begin{array}{l}\text { Series 2,c } \\
\text { Type of } \\
\text { PUF }\end{array}$ & $\begin{array}{l}\text { Density } \\
\text { (gr/cm3) }\end{array}$ & $\begin{array}{l}\text { Average } \\
\text { Density }\end{array}$ \\
\hline PUF 1 & 0.1026 & 0.1156 & PUF 1 & 0.069 & 0.06515 \\
& 0.1707 & & & 0.0664 & \\
& 0.1033 & & & 0.0667 & \\
& 0.0858 & & & 0.0585 & \\
PUF 2 & 0.1791 & 0.1195 & PUF 2 & 0.1214 & 0.1151 \\
& 0.093 & & & 0.1088 & \\
& 0.0908 & & & 0.1214 & \\
& 0.1151 & & & 0.1088 & \\
PUF 3 & 0.1052 & 0.09928 & PUF 3 & 0.0758 & 0.07263 \\
& 0.0956 & & & 0.0754 & \\
& 0.0907 & & & 0.0676 & \\
& 0.1056 & & & 0.0717 & \\
\hline \hline
\end{tabular}

a molding volume $250 \mathrm{ml}$

${ }^{\mathrm{b}}$ Series 1 PU synthesize without Silicone

${ }^{\mathrm{c}}$ Series 2 PU synthesize by used silicone

Table 3. Compressive strength of PUF

\begin{tabular}{lll}
\hline \hline Type of & \multicolumn{2}{l}{ Compressive strenght } \\
\cline { 2 - 3 } Polyurethane & at $10 \%(\mathrm{MPa})$ & Max Load $10 \%(\mathrm{kN})$ \\
\cline { 2 - 3 } PUF1 & $3,06 \times 10^{-3}$ & 17 \\
PUF2 & $3,4 \times 10^{-3}$ & 18 \\
PUF3 & $3,3 \times 10^{-3}$ & 18 \\
\hline \hline
\end{tabular}

${ }^{a}$ PUF was synthesized with silicone using molding $500 \mathrm{ml}$

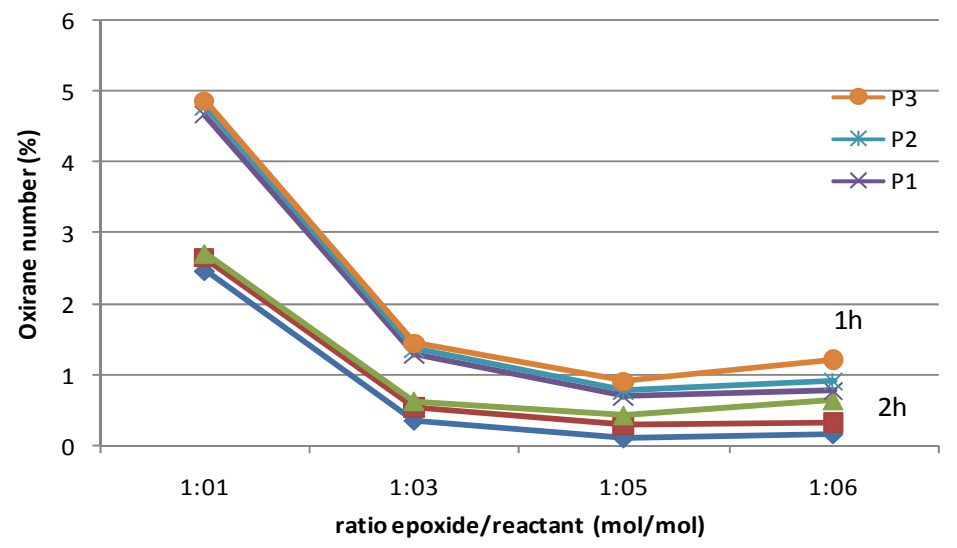

Figure 1. The effect of time to polyol Oxirane number at temperature $110{ }^{\circ} \mathrm{C}$ 


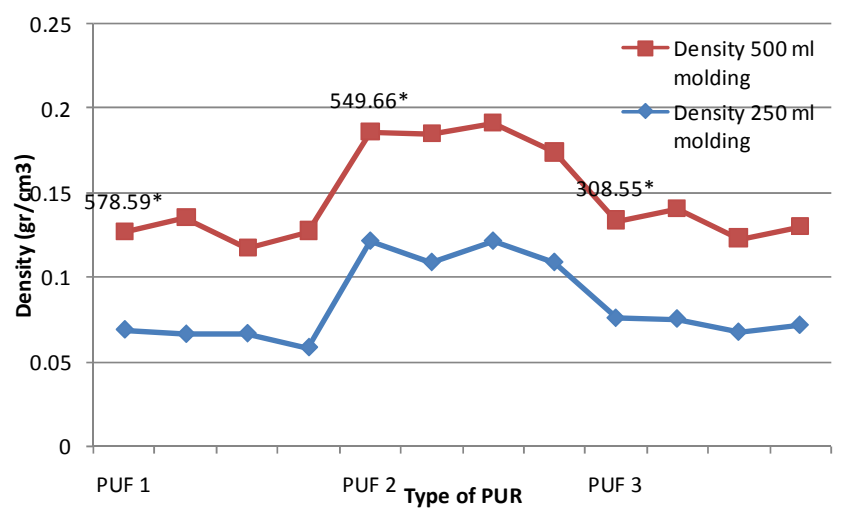

Figure 2. Density of PUF at different volume of molding: $250 \mathrm{ml}$ and $500 \mathrm{ml}$

*Hydroxyl value (mgr $\mathrm{KOH} / \mathrm{gr}$ sample)

PUF was synthesized by silicone

Relationship between hydroxyl value to density

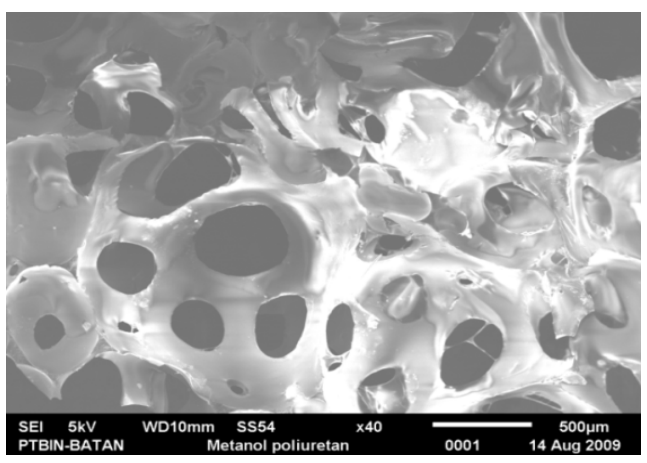

a.PUF1

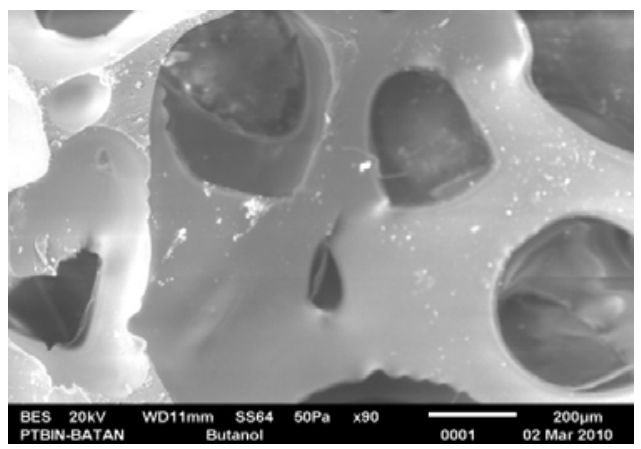

b. PUF 2

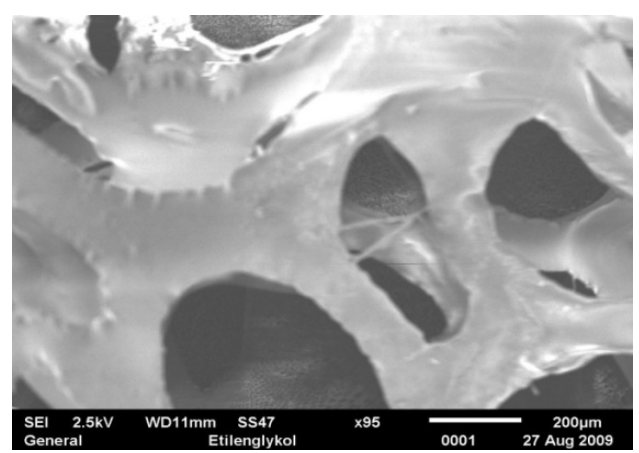

c. PUF3

Figure 3. SEM micrographs of Polyurethane 